\title{
STRUCTURAL CHANGES IN STRUCTURAL STEELS DURING THERMAL CYCLING
}

\author{
Valeriy Gordienko ${ }^{1 *}$, Sergey Repin ${ }^{1}$, Alexander Vorobiev², Angelica Abrosimova ${ }^{1}$ \\ 1Saint Petersburg State University of Architecture and Civil Engineering \\ Vtoraja Krasnoarmeyskaya st., 4, Saint Petersburg, Russia \\ ${ }^{2}$ Emperor Alexander I St. Petersburg State Transport University \\ Moskovsky pr., 9, Saint Petersburg, Russia
}

*Corresponding author: val-gor@yandex.ru

\begin{abstract}
Introduction: During experimental studies of structural steels responsible for the reliability of metal structures used, for example, in hoisting and transporting machinery, we established a correlation between the magnetic parameter Hp and characteristic changes in the metal microstructure during thermal cycling. It is shown that the Hp parameter depends on the initial structural state of steel, the amount and mass fraction of alloying elements, and the number of heating/cooling cycles. Methods: We found that an increase in the number of heating/cooling cycles and the amount of alloying elements, as well as preliminary cold plastic deformation with stage-by-stage control of structural changes using passive magnetic flux leakage testing results in a finer-grained structure, which was confirmed by metallographic analysis. Results: The paper considers specifics of structural changes in steels with different initial structures during thermal cycling. It is shown that the final grain size depends on the number of treatment cycles, the amount of alloying elements, and the initial microstructure. It is the fine-grain structure that improves the most important performance characteristics of steels: strength, cyclic strength, and cold brittleness.
\end{abstract}

\section{Keywords}

Welded metal structures, structural steels, transport and special purpose vehicles, handling machinery, thermal cycling, structural changes, fine-grain structure, metallographic analysis, passive magnetic flux leakage testing, magnetic parameter Hp.

\section{Introduction}

Long-term use of a vast amount of welded metal structures, an increasing number of steel grades used to manufacture various structures of hoisting and transporting machinery, numerous studies to develop and improve new process solutions so as to guarantee the required behavior of metals all of these are not sufficient to obtain valid data on the identification of reliable relations between the microstructure and the magnetic parameters of structural steels. To manufacture more reliable and safe welded metal structures used in various constructions and machinery, we need not only to use the existing ones properly but also to develop new, more accurate instruments and equipment as well as methods for monitoring and restoring their performance (Belyaev et al., 2020 ). It should be noted that in order to optimize material and labor input, reduce the cost of welded metal structures and products, it is necessary to perform nondestructive testing, including magnetic testing, at all stages of their manufacture, installation, operation and repair (Hetherington et al. 1987; Ranjan et al., 1987; Rautioaho et al., 1987; Tanner et al., 1988; Thompson and Tanner, 1993).
It becomes possible with passive magnetic flux leakage testing (Gordienko, 2020; Gordienko and Bardyšev, 2013; Gordienko et al., 2020). We used this method in our study to ensure stage-by-stage control of structural changes in structural steels having different initial microstructures during thermal cycling. Thermal cycling is one of the basic effective ways to obtain ultrafine-grain structures in metals and alloys with various degrees of dispersion, which is essential in civil and mechanical engineering since steels with a fine-grain structure are characterized by higher strength properties.

Heating/cooling cycles in thermal cycling treatment have the following effects on metal: significant rapid changes in temperature during heating/cooling, phase and structure transformations, interfacial and thermal stresses (Fedyukin and Smagorinsky, 1989; Maslakova, 1978; Porter and Dabkowski, 1973; Savitsky, 1971a, 1971b). However, different types of steel have different optimal thermal cycling conditions, which cannot be extended to other types of steel.

\section{Methods}

Taking the above into consideration, it was important to assess the capabilities of passive 
magnetic flux leakage testing when monitoring the structural state of 08ps, 09G2S and 10KhSND structural steels during thermal cycling and attempt to establish a relationship between the magnetic properties and the structural state of the studied steels with different amounts of alloying elements during multiple thermal cycling. To study 08ps, 09G2S and 10KhSND structural steels having different initial structural states (as-received, as-received + hightemperature annealing at $900^{\circ} \mathrm{C}$, and as-received + preliminary cold plastic deformation to a degree of $50 \%$ ), laboratory samples were cut out, which subsequently were subjected to thermal cycling.

The changes in the initial structure of structural steels during thermal cycling were monitored using passive magnetic flux leakage testing. Magnetic measurements in terms of the strength of leakage magnetic field $H p$ were carried out with an IKNM 2-FP magnetometric stress concentration meter before the first and subsequent heating/cooling cycles of thermal cycling, and then diagrams of changes in the $H p$ parameter vs. the number of cycles were plotted.

To perform metallographic analysis, we used the following: a Brilliant 220 precision cutting machine to cut sections; an Opal 460 automatic press for hot pressing of the samples; a Saphir 560 grinding and polishing machine with a Rubin 520 programmable head to ensure automatic dosing of diamond suspensions and grinding to a pre-set depth. When polishing was completed, the samples were subjected to chemical etching before subsequent metallographic analysis.

We also used Carl Zeiss Axio Observer and Leica DMI 5000 metallographic microscopes to study the microstructure of the samples, displaying it on a screen.

The purpose of the study was to develop a method to obtain such a fine-grain structure of steels that would improve their most important performance characteristics: strength, cyclic strength, and cold brittleness.

\section{Results}

All steels under consideration had a common characteristic: during the first two heating/cooling cycles, the most noticeable changes in the magnetic parameter Hp occurred. During subsequent cycles, the magnetic amplitude decreased, and the $\mathrm{Hp}$ values tended to be minimum and close to each other, regardless of the initial state.

Figs. 1-3 show the behavior of the magnetic parameter $\mathrm{Hp}$ in the studied steels having different initial structural states: in a coarse-grain state - after annealing at $900^{\circ} \mathrm{C}$, in a finer-grain (as-received) state, and with the deformed microstructure - after cold plastic deformation, depending on the number of heating/cooling cycles during thermal cycling.

The chemical composition of steels has a significant effect on the $\mathrm{Hp}$ parameter. The most noticeable changes in $\mathrm{Hp}$ are observed in 08ps steel, less significant changes - in 09G2S steel, and the least significant - in 10KhSND low-alloy steel. The initial structure of structural steels also affects the Hp magnetic parameter. For instance, after hightemperature annealing, all steels characterized by a coarse-grain structure - in contrast to steels characterized by a finer-grain structure (as-received state) - experience smaller changes in the $H p$ parameter, starting from the first cycle (Figs. 4, 5). Steels that have undergone preliminary cold plastic deformation (Fig. 6) are characterized by more noticeable changes in the magnetic parameter $\mathrm{Hp}$, especially after the second and third cycles. It should be noted that regardless of the steel grade and the initial structural state, after the fifth cycle of thermal cycling, the difference between the maximum and minimum $H p$ values is no more than $4 \mathrm{~A} / \mathrm{m}$ (Figs. 1-3), which indicates that the studied steels have approximately similar structural states after thermal cycling.

Figs. 7-9 show typical microstructures of 08ps, 09G2S and 10KhSND structural steels in different initial states after thermal cycling. It can be seen that, regardless of the initial structural state, a finegrain structure is formed with a particular degree of dispersion in all steels after the first three heating/ cooling cycles. An increase in the number of cycles to five promotes further grain refinement, however with a lower intensity, which correlates well with the magnetic measurements (Figs. 1-6). Similar results were obtained by Fedyukin and Smagorinsky (1989). Using C30, C40, and C60 carbon steels, they showed that five to six cycles are required to obtain the optimal structure and mechanical properties of steels during thermal cycling.

Grain refinement during the first heating/cooling cycle of thermal cycling is characterized by the following: it starts throughout the entire volume of metal simultaneously, however, in some areas, its intensity varies. This tendency persists until the third cycle, while steels show non-homogeneity in grain size. An increase in the number of heating/ cooling cycles to five reduces non-homogeneity and increases the degree of dispersion, but with a lower intensity.

Such a tendency in the formation of a fine-grain structure during five cycles of thermal cycling and correlated changes in the magnetic properties make it possible to detect different stages of structural changes in structural steels and control the initial and subsequent stages of fine-grain structure formation.

The final structure of steels in thermal cycling depends on their chemical composition (Figs. 7-9). For instance, in the case of 08ps steel, grain size non-homogeneity decreases significantly after the second heating/cooling cycle, in the case of 09G2S steel, which contains silicon and manganese, it decreases after the third cycle, and in the case of 


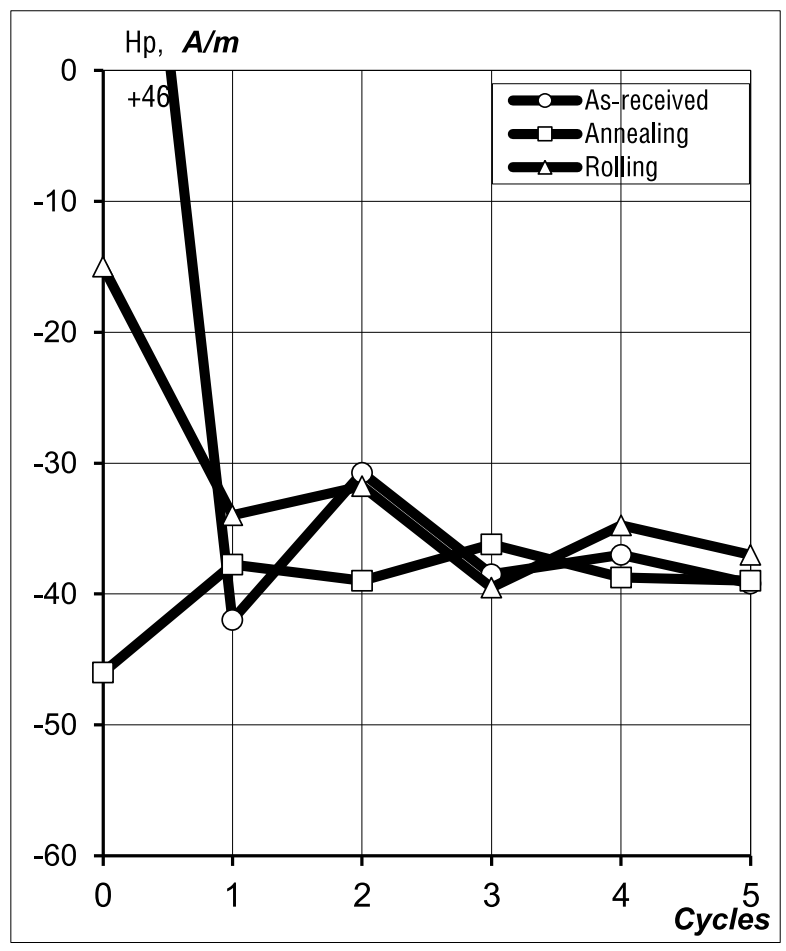

Figure 1. Effect of the number of heating/cooling cycles during thermal cycling on the magnetic parameter $\mathrm{Hp}$ of $08 p s$ steel in different initial structural states

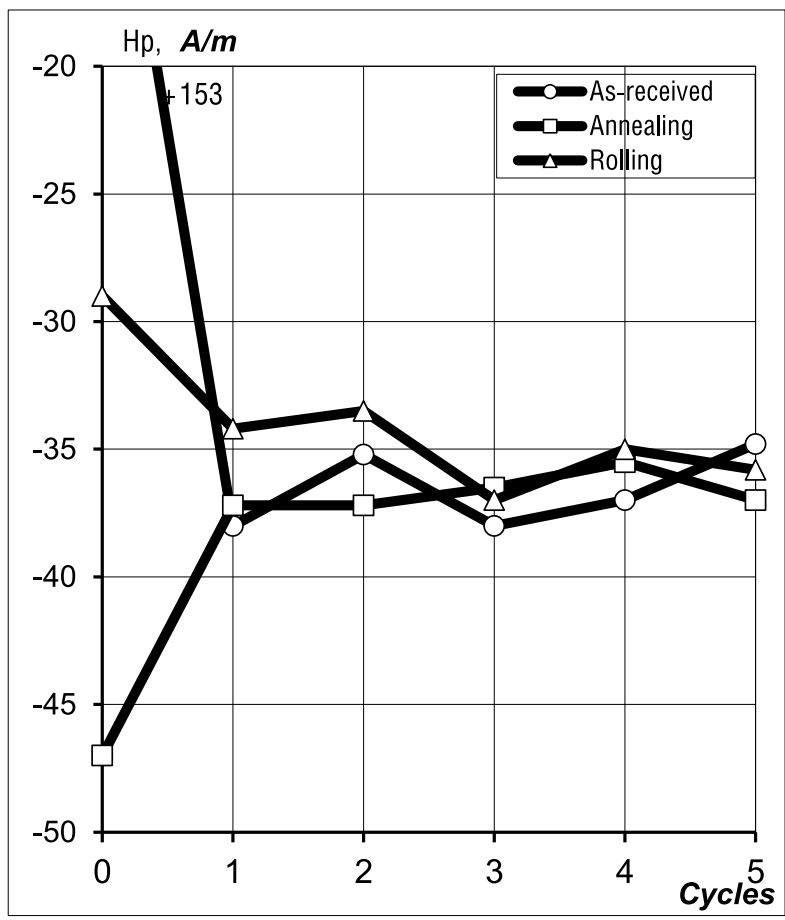

Figure 3. Effect of the number of heating/cooling cycles during thermal cycling on the magnetic parameter $\mathrm{Hp}$ of $10 \mathrm{KhSND}$ steel in different initial structural states

10KhSND steel containing an even greater amount of alloying elements - only after the fourth cycle. Such behavior during thermal cycling is probably due to the different amounts and mass fractions of alloying elements in steels. It should be noted that after the fifth cycle 10KhSND low-alloy steel has

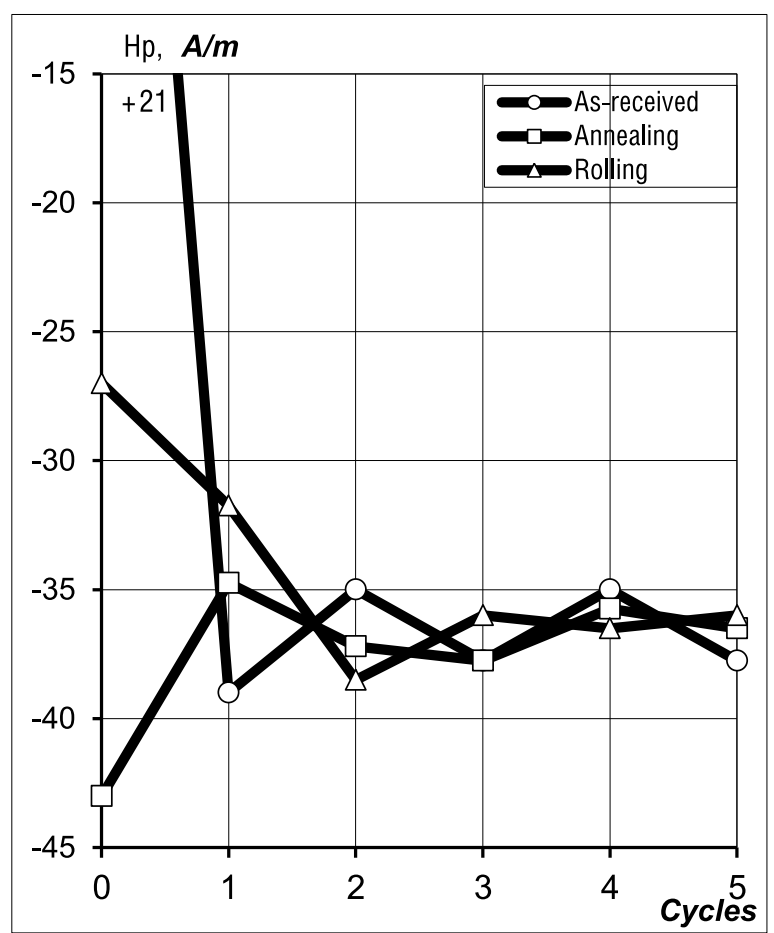

Figure 2. Effect of the number of heating/cooling cycles during thermal cycling on the magnetic parameter $\mathrm{Hp}$ of 09G2S steel in different initial structural states

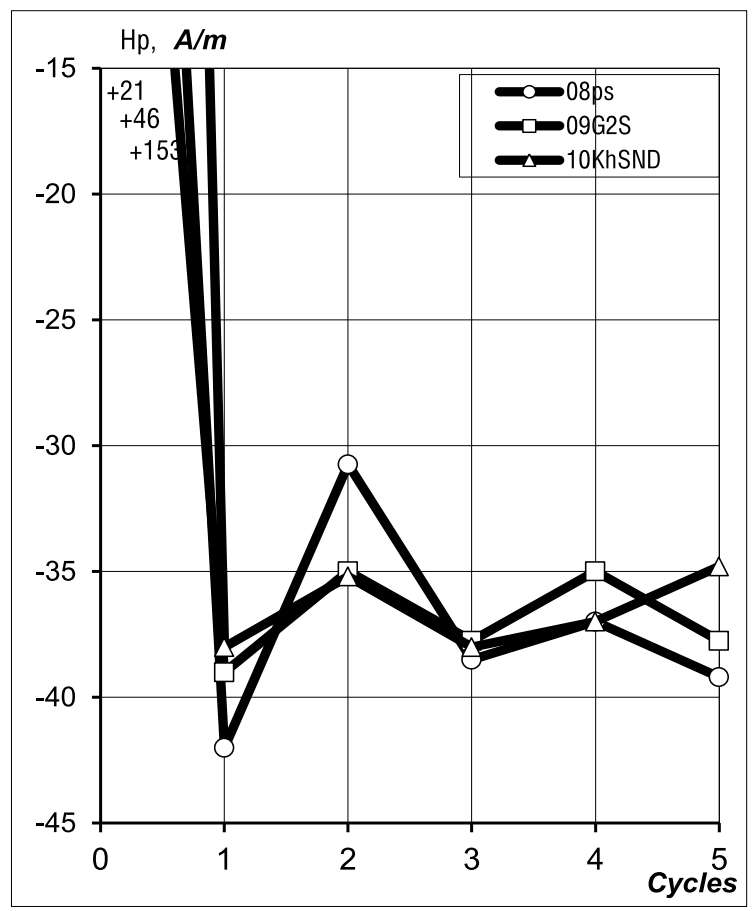

Figure 4. Effect of the number of heating/cooling cycles during thermal cycling on the magnetic parameter $\mathrm{Hp}$ of 08ps, 09G2S and 10KhSND steels in the as-received state

the smallest grain size in comparison with $08 p s$ and 09G2S steels, presented initially in the same structural state.

The same pattern of change in the degree of dispersion of the initial structure in some areas compared with others was noted by Porter and 


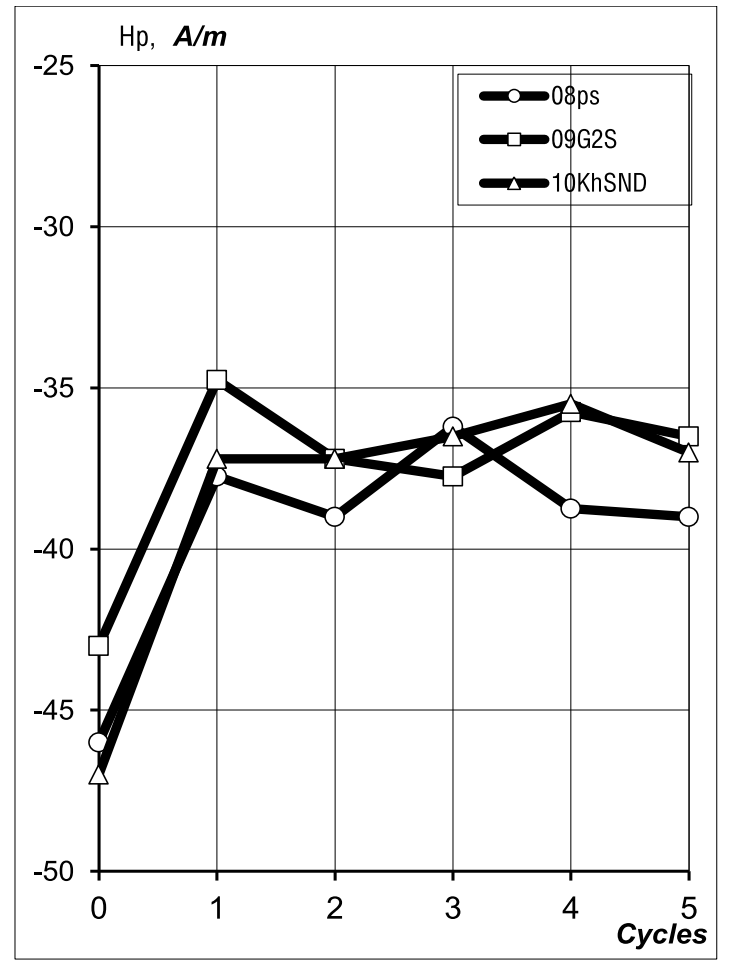

Figure 5. Effect of the number of heating/cooling cycles during thermal cycling on the magnetic parameter $\mathrm{Hp}$ of $08 \mathrm{ps}, 09 \mathrm{G} 2 \mathrm{~S}$ and $10 \mathrm{KhSND}$ steels in the state after annealing at $900^{\circ} \mathrm{C}$

a)

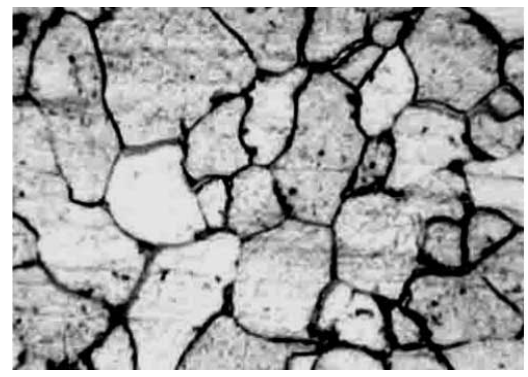

b)

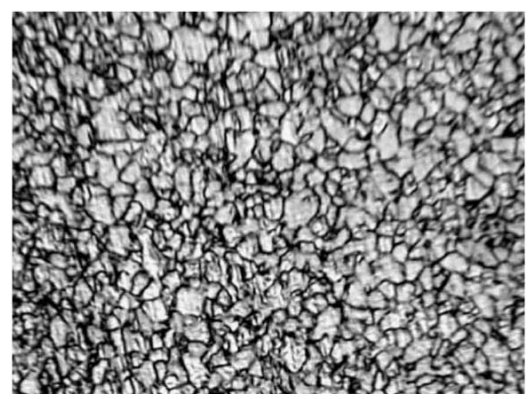

c)

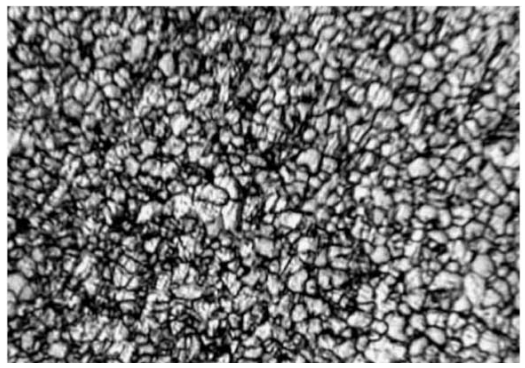

Figure 7. Changes in the structure of $08 \mathrm{ps}$ steel during thermal cycling, $x 650$ :

a - as-received, b, c - after the third and fifth heating/cooling cycles

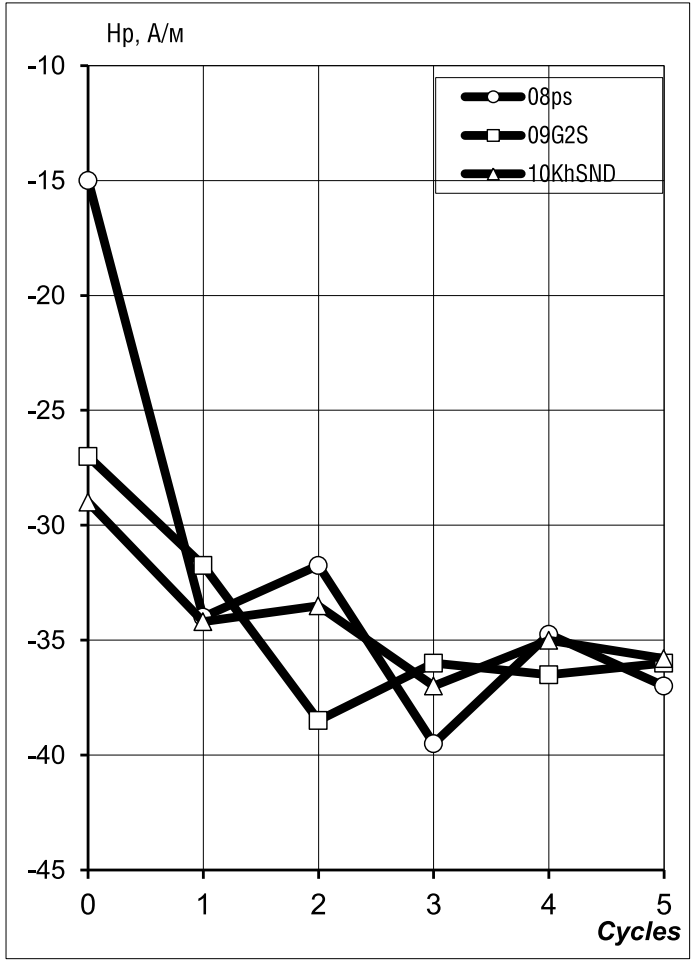

Figure 6. Effect of the number of heating/cooling cycles during thermal cycling on the magnetic parameter $\mathrm{Hp}$ of $08 \mathrm{ps}, 09 \mathrm{G} 2 \mathrm{~S}$ and 10KhSND steels in the state after deformation to $\varepsilon=50 \%$

a)

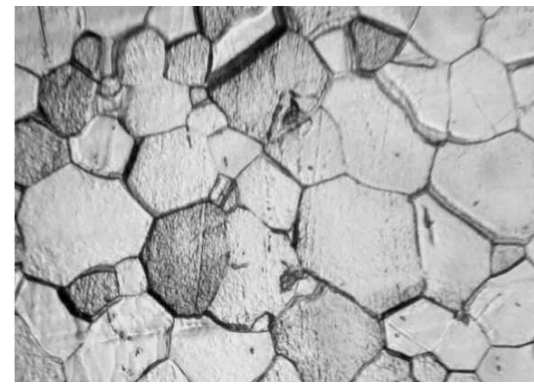

b)

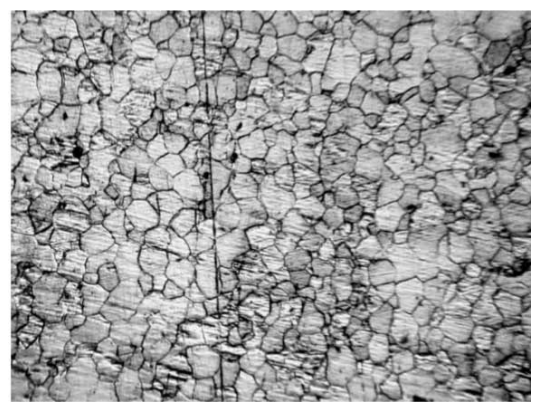

c)

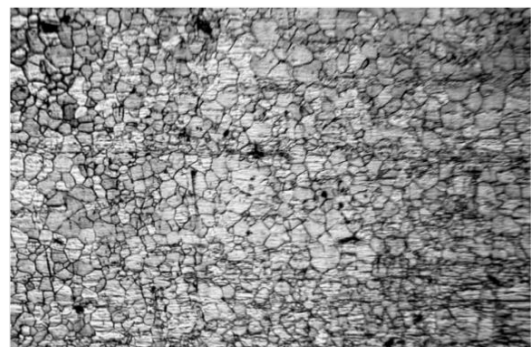

Figure 8. Changes in the structure of 09G2S steel during thermal cycling, $x 650$ :

a - as-received + annealing at $900^{\circ} \mathrm{C}$

b, $c-$ after the third and fifth heating/cooling cycles 
a)

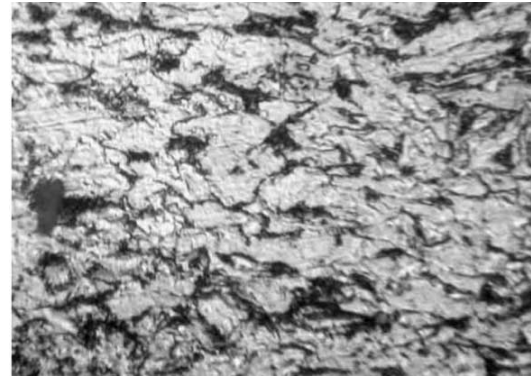

b)

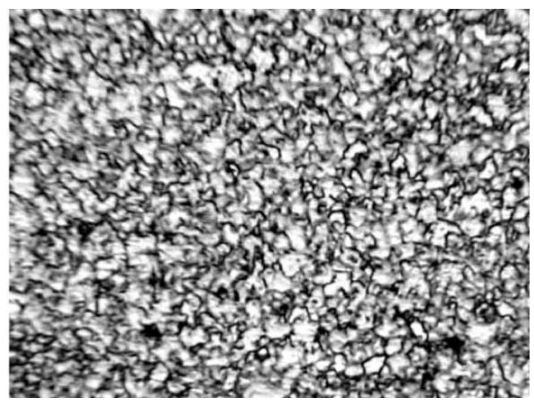

c)

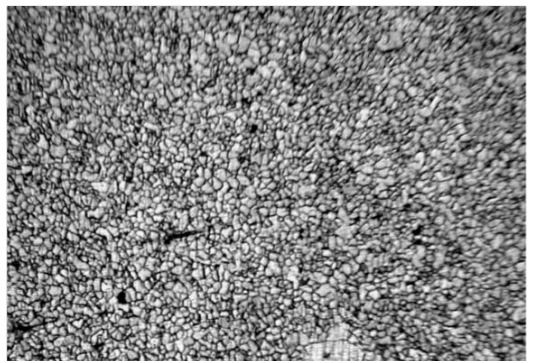

Figure 9. Changes in the structure of $10 \mathrm{KhSND}$ steel during thermal cycling, $x 650$ :

a - as-received + deformation to a degree of $50 \%$, b,

$\mathrm{c}$ - after the third and fifth heating/cooling cycles

Dabkowski (1973). A further increase in the number of heating/cooling cycles promoted structure refinement in all areas.

We should highlight that the presence of certain alloying elements in steels significantly reduces carbon mobility and activity, and this is the reason why changes in the structure of steels during cyclic heating and cooling occur more slowly. Thus, obtaining the final microstructure with the smallest possible grain size in alloy steels requires an increase in the number of cycles as compared with carbon steels. To accelerate structural transformations in steels with alloying elements during thermal cycling, the maximum heating temperature shall be increased by $50 . . .70^{\circ} \mathrm{C}$ above the $\mathrm{Ac}_{1}$ point. The initial microstructure of structural steels (coarse-grain, finegrain, deformed) has a very significant effect on the formation of the final structure during multiple thermal cycling. In the case of a coarse-grain initial structure (after annealing at $900^{\circ} \mathrm{C}$, Fig. 8) - in comparison with a finer-grain structure (as-received, Fig. 7) - a coarse-grain structure is formed after the third and fifth cycles of thermal cycling.

In the case of a deformed initial structure, the finest-grain structure is formed (Fig. 9) during thermal cycling as compared with other types of treatment.
This is probably due to greater activation of structural transformations occurring during cyclic heating and subsequent cooling of steels. Significant structural changes in cold-deformed steels lead to changes in the $H p$ parameter during cyclic heating and cooling. Fig. 6 shows that the $H p$ values after the fourth and fifth cycles are almost equal, which indicates that intensive grain refinement is completed and an ultrafine-grain structure is formed.

\section{Discussion}

The developed modes of thermal cycling for structural steels in different initial structural states (as-received, after high-temperature annealing, after plastic deformation) with stage-by-stage control of structural transformations using passive magnetic flux leakage testing make it possible to obtain final fine-grain structures in steels.

Extra-strong structural steels having such a finegrain structure can be used in critical components of metal structures and machine parts, exposed to high loads. Thermal cycling can be used to enhance the strength properties of metal in dangerous local stress concentration areas according to the results of diagnostics regarding the technical condition of constructions and machinery characterized by longterm operation.

\section{Conclusion}

1. We found the relationship between the magnetic parameter $\mathrm{Hp}$ and changes in the initial structure of $08 \mathrm{ps}, 09 \mathrm{G} 2 \mathrm{~S}$ and $10 \mathrm{KhSND}$ structural steels during thermal cycling. We also established that the $H p$ value depends on the degree of alloying, the initial structural state, and the number of heating/ cooling cycles.

2. An increase in the number of cycles to three significantly increases the degree of refinement of the initial microstructure. An increase in the number of cycles to five reduces the grain size with a lower intensity but more significantly reduces grain size non-homogeneity.

3. With an increased amount of alloying elements, it is possible to form a finer-grain structure. Preliminary cold plastic deformation allows us to obtain the most dispersed microstructure.

4. The developed method of thermal cycling treatment for 08ps, 09G2S and 10KhSND structural steels makes it possible to obtain finegrain structures with specified grain size (which enhances the strength properties of metal), which can be used to manufacture welded metal structures, bearing elements and operating parts of transport and special purpose vehicles as well as handling machinery. Thermal cycling with stage-by-stage magnetic control of structural transformations can be used to strengthen metal in dangerous local areas and closed contours in order to extend service life, improve reliability and operating safety, and reduce the risk of failures and accidents. 


\section{References}

Belyaev, A., Gordienko, V., Druzhinin, P. and Evtukov, S. (2020). Mathematical model for selecting the best technology for restoring road construction machines. E3S Web of Conferences, Vol. 164, Article 03044. DOI: 10.1051/ e3sconf/202016403044.

Fedyukin, V. K. and Smagorinsky, M. Ye. (1989). Thermal cycling treatment of metals and vehicle components. Leningrad: Mashinostroyeniye, Leningrad Department, $255 \mathrm{p}$.

Gordienko, V. (2020). Magnetic control of structural changes in structural steels during plastic deformation. E3S Web of Conferences, Vol. 164, Article 08023. DOI: 10.1051/e3sconf/202016408023.

Gordienko, V. and Bardyšev, O. (2013). Investigation of influence by the cold plastic deformation of metals on magnetic intensity of scattering. World Applied Sciences Journal 23 (Problems of Architecture and Construction), pp. 74-79. DOI: 10.5829/idosi.wasj.2013.23.pac.90016.

Gordienko, V., Chernykh, A. and Repin, S. (2020). Influence of recrystallization annealing regime on the formation of a fine-grained structure in structural steels. E3S Web of Conferences, Vol. 164, Article 08021. DOI: 10.1051/ e3sconf/202016408021.

Hetherington, M. G., Jakubovics, J. P., Szpunar, J. F. and Tanner, B. K. (1987). High-voltage Lorentz electron microscopy studies of domain structures and magnetization processes in pearlitic steels. Philosophical Magazine B, Vol. 56, Issue 5, pp. 561-577. DOI: 10.1080/13642818708220163.

Maslakova, T. M. (1978). Effect of thermal cycling $(\mathrm{V} \rightleftarrows \alpha)$ on the properties of maraging steel. Metal Science and Heat Treatment, No. 20, pp. 991-995. DOI: 10.1007/BF00703274.

Porter, L. F. and Dabkowski, D. S. (1973). Grain-size control by thermal cycling. In: Gordienko, L. K. (ed.) Ultra-fine grain metals. Moscow: Metallurgiya, pp. 135-163.

Ranjan, R., Jiles, D. C. and Rastogi, P. K. (1987). Magnetic properties of decarburized steels: An investigation of the effects of grain size and carbon content. IEEE Transactions on Magnetics, Vol. 23, No. 3, pp. 1869-1876. DOI: 10.1109/TMAG.1987.1065175.

Rautioaho, R., Karjalainen, P. and Moilanen, M. (1987). Stress response of Barkhausen noise and coercive force in 9Ni steels. Journal of Magnetism and Magnetic Materials, Vol. 68, pp. 321-327. DOI: 10.1016/0304-8853(87)90008-4.

Savitsky, Ye. M. (1971a). Effect of thermal cycling on the fine structure and properties of molybdenum single crystals. In: Savitsky, Ye. M. (ed.) Single crystals of refractory and rare metals. Moscow: Nauka, pp. 119-124.

Savitsky, Ye. M. (1971b). Effects of thermal cycling on the single crystals of tungsten and molybdenum alloys. Proceedings of the Academy of Sciences, Vol. 198, No. 2, pp. 373-376.

Tanner, B. K., Szpunar, J. A., Willcock, S. N. M., Morgan, L. L. and Mundell, P. A. (1988). Magnetic and metallurgical properties of high-tensile steels. Journal of Materials Science, Vol. 23, pp. 4534-4540. DOI: 10.1007/BF00551956.

Thompson, S. M. and Tanner, B. K. (1993). The magnetic properties of pearlitic steels as a function of carbon content. Journal of Magnetism and Magnetic Materials, Vol. 123, Issue 3, pp. 283-298. DOI: 0.1016/0304-8853(93)90454-A. 


\title{
СТРУКТУРНЫЕ ИЗМЕНЕНИЯ В КОНСТРУКЦИОННЫХ СТАЛЯХ ЭЛЕМЕНТОВ ТРАНСПОРТНО-ТЕХНОЛОГИЧЕСКИХ МАШИН ПРИ ТЕРМОЦИКЛИЧЕСКОЙ ОБРАБОТКЕ
}

\author{
Валерий Евгеньевич Гордиенко ${ }^{1 *}$, Сергей Васильевич Репин ${ }^{1}$, Александр Алфеевич Воробьев², \\ Анжелика Анатольевна Абросимова ${ }^{1}$
}

${ }^{1}$ Санкт-Петербургский государственный архитектурно-строительный университет 2-ая Красноармейская ул., 4, Санкт-Петербург, Россия

2Петербургский государственный университет путей сообщения Императора Александра I

Московский пр., 9, Санкт-Петербург, Россия

*E-mail: val-gor@yandex.ru

\begin{abstract}
Аннотация
В процессе экспериментальных исследований на конструкционных сталях, определяющих надежность металлоконструкций, например, таких транспортно-технологических машин, как грузоподъемные и транспортирующие, установлена корреляционная связь магнитного параметра Нр с характерным изменением микроструктуры при термоциклической обработке. Показано, что определяющее влияние на параметр Нр оказывает начальное структурное состояние стали, число и массовая доля легирующих элементов, число проведенных циклов нагрев-охлаждение при обработке. Методы: Установлено, что повышение количества циклов нагрев-охлаждение, количества легирующих элементов, а также проведение предварительной холодной пластической деформации при поэтапном контроле структуры сталей пассивным фреррозондовым методом приводит к получению более мелкозернистой структуры в сталях, что было подтверждено методом металлографического анализа. Результаты: Рассмотрены некоторые особенности структурных изменений в сталях с разной начальной структурой при термоциклической обработке. Показано, что конечный размер зерен зависит как от числа циклов обработки, количества легирующих элементов, так и от начальной микроструктуры сталей. Именно мелкозернистая структура сталей обеспечивает повышение важнейших эксплуатационных характеристик: прочности, циклической прочности, хладноломкости.
\end{abstract}

\section{Ключевые слова}

Сварные металлические конструкции, конструкционные стали, транспортно-технологические машины, термоциклическая обработка, структурные изменения, мелкозернистая структура, металлографический анализ, пассивный феррозондовый метод контроля, магнитный параметр Нp. 